\title{
Hybrid Process of Electrochemistry with Magnetite Nanoparticles for Treatment of Turbid Water
}

\author{
Thamer Jasim Mohammed ${ }^{1}$, and Hadeel Atiya Al-Zuheri ${ }^{2, *}$ \\ ${ }^{1}$ Department of Chemical Engineering, University of Technology, Baghdad, Iraq, thamer_jasim58@yahoo.com \\ ${ }^{2}$ Department of Chemical Engineering, University of Technology, Baghdad, Iraq, che.80318@uotechnology.edu.iq \\ *Corresponding author: Hadeel Atiya Al-Zuheri,email: che.80318@uotechnology.edu.iq \\ Published online: 31 August 2019.
}

Abstract-Magnetic nanoparticles are now being investigated widely in field of water treatment. The aim of this study was to evaluate the feasibility of electrocoagulation process combined with addition of magnetite nanoparticles as a turbidity removal process. Bentonite was used as source of turbidity for the synthetic turbid water. Experiments were conducted in a bench scales electrocoagulation reactor where voltage was applied across a perforated plate of aluminum as anode, and iron mesh as cathode. Commercial grade of magnetite (Fe3O4) with an average nanoparticle size of $50 \mathrm{~nm}$ was used. The effect of some factors such as initial $\mathrm{pH}$ of the solution (5-9), current density $(5-25 \mathrm{~mA} / \mathrm{cm} 2)$, and magnetite dosage (0.4-2.5 gm) on the efficiency of the process were studied. The residual turbidity obtained by using electrocoagulation process alone was $(7.47 \mathrm{NTU})$ from initial turbidity of $(200 \mathrm{NU})$ at constant conditions of $\mathrm{pH} 6$, current density $15 \mathrm{~mA} / \mathrm{cm} 2$ and electrolysis time $20 \mathrm{~min}$. While under these same conditions the combined electrocoagulation + magnetite process with the added $(1.4 \mathrm{gm})$ of magnetite and under the same operating conditions the residual turbidity was $(4.34 \mathrm{NTU})$, which indicate that the magnetite nanoparticles enhanced the electrocoagulation process.

Keywords- Electrocoagulation, Magnetite, Water treatment, Turbidity.

\section{Introduction}

Turbidity is one of the main problems in the water treatment field. Turbidity is produced through the existence of clay or/and different colloidal components in water such as organic particles, soluble substances, and algae. These colloids have stability which make them cannot be sedimented. Thus, agglomerate small particles to bigger flocs is needed so they can be removed by sedimentation [13]. Recently, electrocoagulation is having a noticeable role in the treatment of water since it offers several important benefits, for example easiness in operation, no addition of chemicals, quite compactness, and less sludge production [18]. Electrocoagulation process include the producing of aluminum or iron hydroxides flocs in the solution. In this process coagulant is formed in situ by the passage of current density through the sacrificial anode which leads to its dissolution [3]. Three steps occur during electrocoagulation a) electrolytic reaction at surface of the electrode, b) coagulants formation by electrolytic oxidation in aqueous phase and colloidal particles adsorption by the coagulants, and c) separation by sedimentation or flotation which is initiated by the evolution of $\mathrm{H} 2$ bubbles at the cathode. Therefore, it's important to choose the appropriate material for the anode. Iron or aluminum is usually used as sacrificial anode, since they are cheap, readily available [17]. When aluminum electrode is used in the EC process, the main reaction in the anode will be [15]:

At the anode:

$$
\mathrm{Al}(\mathrm{s}) \rightarrow \mathrm{Al} 3+(\mathrm{aq})+3 \mathrm{e}^{-}
$$

At the cathode:

$$
3 \mathrm{H} 2 \mathrm{O}+3 \mathrm{e}^{-} \rightarrow 3 / 2 \mathrm{H} 2+3 \mathrm{OH}^{-}
$$

The produced $\mathrm{Al}+3$ from reaction (1) react with water and $\mathrm{OH}-$ to generate different monomeric constituents, based on the $\mathrm{pH}$ of solution, finally they convert to $\mathrm{Al}(\mathrm{OH}) 3$ based on the kinetic of complex reactions. In the solution the total reaction will be as [15]:

$$
\mathrm{Al} 3+(\mathrm{aq})+3 \mathrm{H} 2 \mathrm{O} \rightarrow \mathrm{Al}(\mathrm{OH}) 3(\mathrm{~s})+3 \mathrm{H}+(\mathrm{aq})
$$


Poly-hydroxides and hydroxides which have been formed, will stay as gelatinous suspensions in the solution, that they can cause destabilization of the emulsion by the neutralization of the colloidal charges [1]. However, because of the various composition of wastewater, conventional processes are insufficient and cannot be utilized separately in full scale. Scientists are trying to purpose combination between the methods of treatment to obtain high removal efficiencies of contaminants [5]. Combination of electrocoagulation with magnetite nanoparticles was used for the removal of arsenic from copper smelter wastewater [12]. These magnetic nanoparticles have high adsorption capacity and surface area, thus it may be utilized as a super adsorbent for pollutants separation from effluents and at the end they may be removed from solution by external magnetic field [8]. In this study magnetite nanoparticles (MNPs) are added to the electrocoagulation process to enhance the removal of turbidity from synthetic turbid wastewater. The effect of three factors on turbidity removal will be investigated: initial $\mathrm{pH}$ of solution, current density, and magnetite dosage.

\section{Experimental work}

\subsection{Turbid water preparation}

The turbid sample was prepared by mixing (0.3 gm) sodium bentonite with distilled water containing $1720 \mathrm{ppm}$ dissolved $\mathrm{NaCl}$ by using high speed mixer of $2000 \mathrm{rpm}$ to give water a turbidity of (200 NTU). Sodium bentonite was supplied by Research and Development Oil Center, Iraq. Turbidity in samples was measured before and after treatment by using Lovibond TurbDirect model /serial number 12/1805 with measurement unit NTU (Nephlometric turbidity unit) within the range $(0.00-$ 1000) NTU.

\subsection{Magnetite nanoparticle characteristics:}

Commercial grade of magnetite nanoparticles with the characteristics listed in Table. 1 was employed as the magnetic sorbent particles for the experiments. These nanoparticles were analyzed with scanning electron microscopy (SEM) Fig. 1. The micrograph of bare magnetite particles showed that magnetite is in the nanoscale and have spherical shape with a diameter $50 \mathrm{~nm}$. The $\mathrm{pH}$ of zero-point charge (pHpzc) of magnetite nanoparticles were measures so as to understand the charge of the adsorbent surface. Zeta potential of magnetite solution at different $\mathrm{pH}$ values was measures in (Iraqi Ministry of Higher Education and Scientific Research) using NanoBrook ZetaPALS Potential Analyzer
Table 1: Magnetite Characteristics

\begin{tabular}{|c|c|}
\hline Magnetite & Properties \\
\hline Chemical formula & Fe3O4 \\
\hline Molecular Weight & 536.39 \\
\hline Radius & $50 \mathrm{~nm}$ \\
\hline Purity & $99.9 \%$ \\
\hline Shape & Sphere \\
\hline Color & Black \\
\hline
\end{tabular}

\subsection{Experimental Set-up}

As shown in Fig. 3 and Fig. 4, experiments were conducted in a batch electrocoagulator consisted of a Perspex compartment with total volume 2.5 liters and dimensions $20 \mathrm{~cm}$ in length, $14 \mathrm{~cm}$ in width and $16 \mathrm{~cm}$ height. Perforated aluminum plate and iron mesh $(150 \mathrm{~mm}$ in length, $45 \mathrm{~mm}$ in height and of $0.4 \mathrm{~mm}$ thickness) was used as anode and Cathode respectively. The active area of anode was $89.29 \mathrm{~cm} 2$ and the distance between electrodes was $3 \mathrm{~cm}$ as in [16].

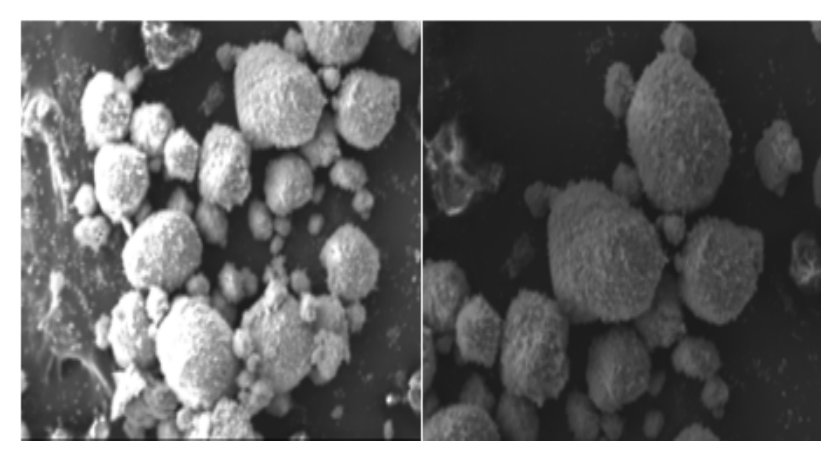

Figure 1: SEM images of magnetite nanoparticles.

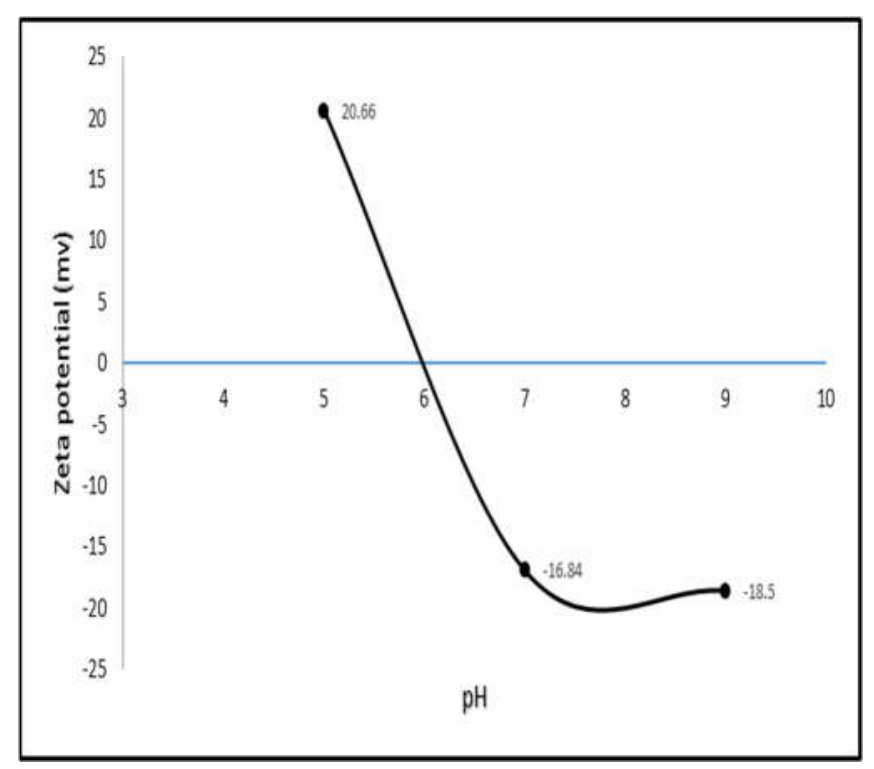

Figure 2: Zeta potentials of magnetite nanoparticles at different $\mathrm{pH}$ values. 
A DC power supply (MODEL: APS3005S) with variable output of (0-30 V), and current (0-5 A) was used as direct current source

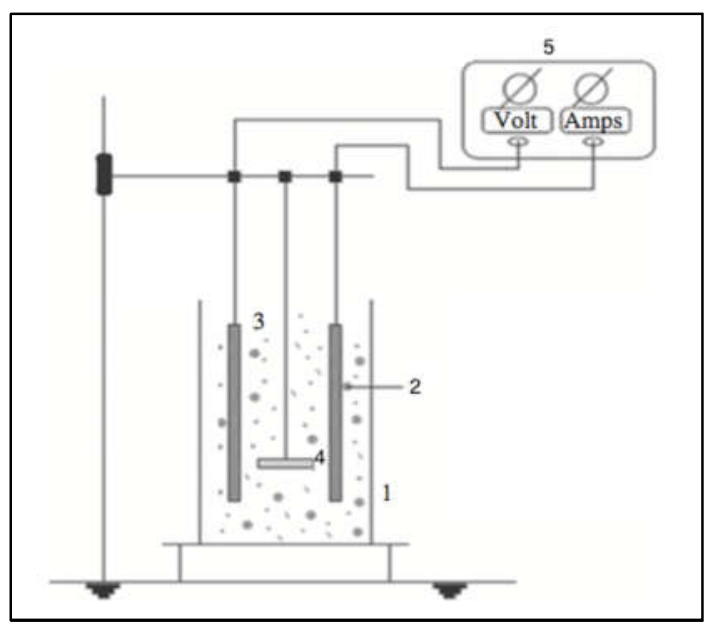

Figure 3: Experimental set up

\subsection{Experimental procedure}

The experiments were done by introducing $1500 \mathrm{~mL}$ wastewater samples to the batch reactor for each experiment. The influence of three factors on the removal efficiency of turbidity was examined at five different level as shown in Table. 2. The $\mathrm{pH}$ of the solution was changed by using of $(0.1 \mathrm{~N}) \mathrm{HCl}$ and $(0.1 \mathrm{~N}) \mathrm{NaOH}$. To ensure good mixing, mechanical stirrer was used at $150 \mathrm{rpm}[2,7]$. Magnetite nanoparticles were added at different dosage to the center of the vortex before connecting the DC power to the electrodes, and allowed to contact

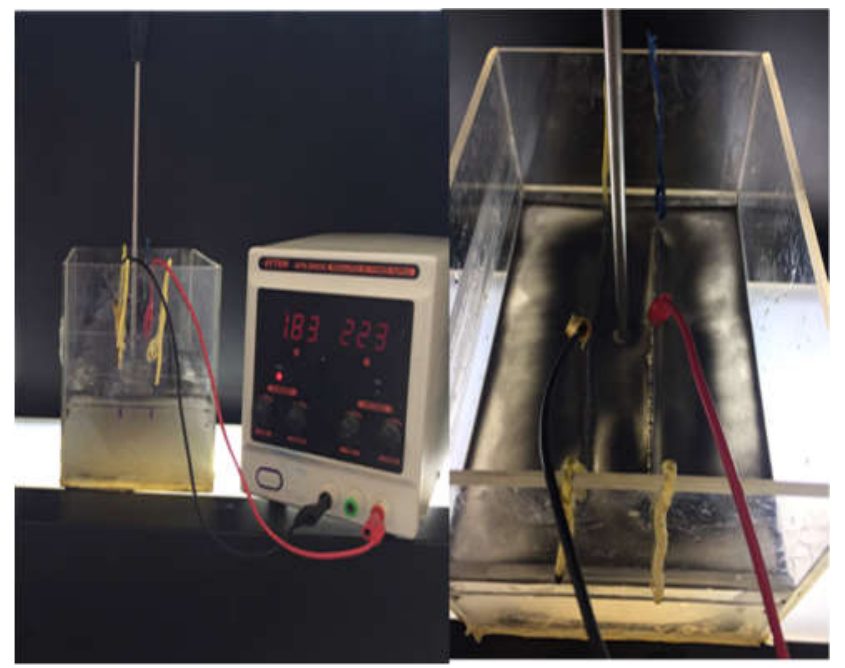

Figure 4: Photographic picture of the experimental set up

with the turbid water for adsorption to take place at 300 $\mathrm{rpm}$ and for $3 \mathrm{~min}$ [9]. After the end of each experiment, the treated water was allowed to settle for $(10 \mathrm{~min})$ [10]. Then samples were collected from fixed position between the cathode and anode about $(3 \mathrm{~cm})$ below the water surface to avoid collecting sediment floc from the bottom and floated floc from the top of the water. Removal efficiency of the oil was computed as follows:

Removal efficiency $=\left(\mathrm{C}_{\circ}-\mathrm{Ce}\right) / \mathrm{C}_{\circ} * 100$

Where $\mathrm{CO}$ is the initial turbidity (NTU) and Ce is turbidity at any time.

Table 2: Studied Factors and theirs corresponding levels

\begin{tabular}{|c|c|c|c|c|c|}
\hline Factors & \multicolumn{5}{|c|}{ Factors level } \\
\hline $\mathrm{pH}$ & 5 & 6 & 7 & 8 & 9 \\
\hline $\begin{array}{c}\text { Current density } \\
(\mathrm{mA} / \mathrm{cm} 2)\end{array}$ & 5 & 10 & 15 & 20 & 25 \\
\hline $\begin{array}{c}\text { Magnetite } \\
\text { dosage }(\mathrm{g} / \mathrm{L})\end{array}$ & 0.27 & 0.6 & 0.93 & 1.26 & 1.6 \\
\hline
\end{tabular}

\section{Results and Discussion}

\subsection{Effect of initial $\mathrm{pH}$ :}

In order to study the effect of the $\mathrm{pH}$ on turbidity removal, experiments were performed by adjusting the initial $\mathrm{pH}$ to five different values of $(5,6,7,8$, and 9). Figure (5) shows a comparison for $\mathrm{EC}$ process alone and the combination of $\mathrm{EC}+$ magnetite. In both processes the minimum residual turbidity was obtained at neutral $\mathrm{pH} \mathrm{6-7,} \mathrm{the} \mathrm{residual}$ turbidity then started to increase as the $\mathrm{pH}$ increased. This is due that aluminum hydroxide $\mathrm{Al}(\mathrm{OH}) 3$ is produced at $\mathrm{pH}(6-7)$ which is a precursor for the removal of turbidity by coagulation and its insoluble form of $(\mathrm{Al}+3)$. The increase in final turbidity at basic acidic medium, is because of the aluminum hydroxide $\mathrm{Al}(\mathrm{OH}) 3$ amphoteric state that becomes more soluble as the surrounded medium becomes more acidic or alkaline [4]. As shown in Fig. 5 the EC process gave a final turbidity at $\mathrm{pH}=6$ of $7.47 \mathrm{NTU}$, while in the EC+ magnetite process, residual turbidity at the same conditions was 4.34 NTU which indicate the adsorption of pollutants by the magnetite nanoparticles. The uptake of magnetite nanoparticles for the turbidity decreased as $\mathrm{pH}$ increased.

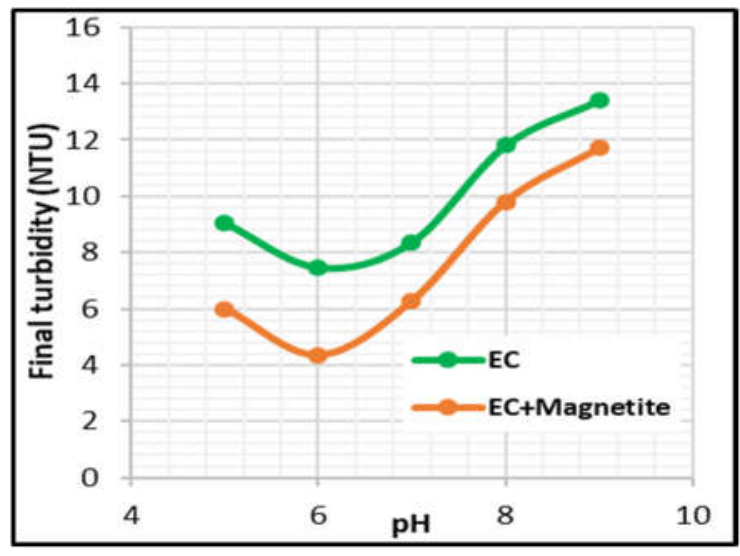

Figure 5 :Comparison of the effect of $\mathrm{pH}$ on final turbidity between $\mathrm{EC}$ and $\mathrm{EC}+$ magnetite process [Current density $=15 \mathrm{~mA} / \mathrm{cm} 2$, Time $=20 \mathrm{~min}$, magnetite dosage $=1.4 \mathrm{gm}$, initial turbidity $=200 \mathrm{NTU}]$ 
It appears in Fig. 2 that the pHPZC of magnetite nanoparticles was equal to 6 which means below the pHPZC the surface charge density of magnetite becomes positive due to the protonation of magnetite nanoparticles, which favor the adsorption of negative charged turbidity due to electrostatic attraction [11]. But as observed at $\mathrm{pH}$ values higher than pHPZC turbidity removal is still happening by the magnetite nanoparticle which can be explained by that: the positive, negative, and neutral functional groups may exist together on the surface of $\mathrm{Fe} 3 \mathrm{O} 4$. When $\mathrm{pH}<\mathrm{pHPZC}$, the groups of $\mathrm{FeOH} 2+$ is more than the groups of FeO-, that mean even though there is positive charge on the surface of nanoparticles, the groups of FeO- still exist and vice versa [6].

\subsection{Effect of current density:}

Five current densities $(5,10,15,20,25 \mathrm{~mA} / \mathrm{cm} 2)$ were tested for the treatment of the turbid water. Results shown in Fig. 6 are expressed in form of the residual turbidity verses different values of current densities for both processes. The residual turbidity decreased as current density increased for both processes.

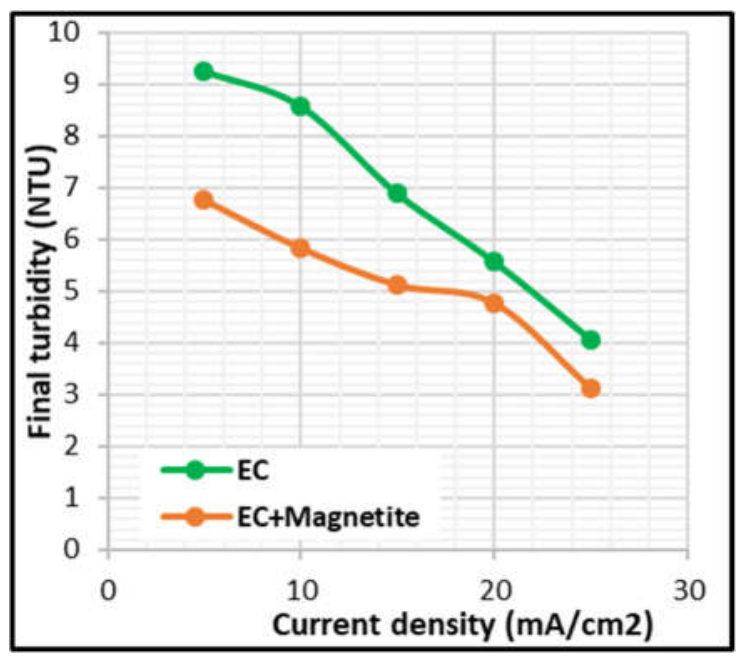

Figure 6: Comparison of the effect of current density on final turbidity between EC and EC + magnetite process $[\mathrm{pH}=7$, Time $=20 \mathrm{~min}$, magnetite dosage $=1.4 \mathrm{gm}$, initial turbidity $=200 \mathrm{NTU}]$

This is because of the increase in the $(\mathrm{Al}+3)$ concentration and their hydroxide flocs that adsorb pollutants as current density increases according to Faraday's law, thus turbidity removal increased. Another effect of the high current density is the increase of rate of generation of the hydrogen bubbles and the decrease of their size that is beneficial for turbidity removal [14]. However, the residual turbidity achieved in EC process alone in $(20 \mathrm{~min})$ electrolysis time and $(10 \mathrm{~mA} / \mathrm{cm} 2)$ was $(8.59 \mathrm{NTU})$. While with the enhancing of the magnetite, the $\mathrm{EC}$ process obtained was (5.84 NTU) at the same condition. We can conclude from the comparison between EC and (EC + magnetite) processes in Fig. 6 that the adsorption of magnetite nanoparticles, decreased as the current density increased. This may be attributed to the increasing in the formation of (OH-) at the cathode as current density increase which causes the deprotonation of the $\mathrm{Fe}-\mathrm{OH}$ sites existing on the surface $(\mathrm{Fe}-\mathrm{OH}=\mathrm{Fe}-\mathrm{O}-+\mathrm{H}+)$, and the formation of negative charge at the surface of nanoparticles and hence less adsorption [19].

\subsection{Effect of magnetite dosage:}

Figure (7) presents the effect of magnetite dosages $(0.27$, $0.6,0.93,1.26$, and $1.6 \mathrm{~g} / \mathrm{L}$ ) on turbidity reduction. As the magnetite dosage increased, the final turbidity in the treated water reduced. In Fig. 6 it could be seen that the minimum residual turbidity was 2.33 NTU from initial turbidity of 200 NTU at magnetite dosage of $(0.9 \mathrm{~g})$ which means this is the optimum dosage. The increasing in magnetite dosage provides more surface area and thus more sites available for the adsorption of turbidity. But the increasing of the dosage behind the optimum level increase the probability of collision between the nanoparticles and thus particles aggregation is formed resulting in decreasing the total surface area and an increasing the diffusional path length, which both contribute to the decrease in the removal efficiency [20].

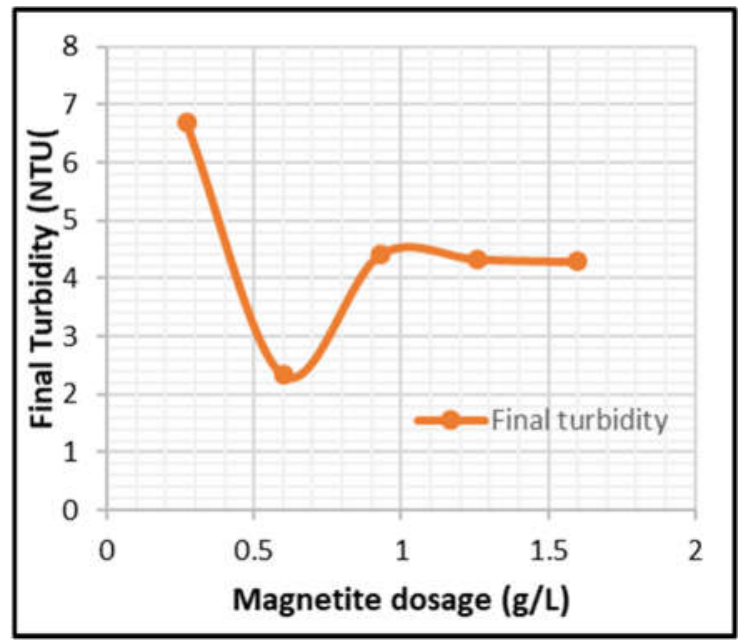

Figure 7: Effect of magnetite dosage on final turbidity between $\mathrm{EC}$ and $\mathrm{EC}+$ magnetite process [Current density $=15 \mathrm{~mA} / \mathrm{cm} 2, \mathrm{pH}=7$, Time $=20 \mathrm{~min}$, initial turbidity $=200 \mathrm{NTU}]$.

\section{Conclusions}

The present study attempted to investigate the applicability for the combination of electrocoagulation with magnetite nanoparticles in the removal of turbidity. The results showed that the EC process and magnetite adsorption both are affected by the initial $\mathrm{pH}$ of the solution. Optimum $\mathrm{pH}$ value was 6 and further increasing for the initial $\mathrm{pH}$ results in increasing the residual turbidity. Current density was also an important factor that the removal of turbidity increased by increasing current density, but it also affected the adsorption of the magnetite nanoparticles. The amount of the magnetite played a significant role too and the 
optimum magnetite dosage was $(0.9 \mathrm{gm})$ and further increasing led to increasing in the residual turbidity. Finally, the results proved that electrocoagulation process was enhanced successfully by the magnetite nanoparticles.

\section{References}

[1] Abdel-Aziz, M. H., El-Ashtoukhy, E- S. Z., Zoromba, M. Sh., Bassyouni, M., (2016), "Oil-inwater Emulsion Breaking by Electrocoagulation in a Modified Electrochemical Cell”, Int. J. Electrochem. Sci., 11, 9634-9643.

[2] Bayar, S., Yildiz, Y.S., Yilmaz, A.E., Irdemez, S., (2011), "The effect of stirring speed and current density on removal efficiency of poultry slaughterhouse wastewater by electrocoagulation method", Desalination 280 (1e3), 103e107.

[3] Bazrafshan, E., Ownagh, K. A., \& Mahvi, A. H., (2012) "Application of electrocoagulation process using Iron and Aluminum electrodes for fluoride removal from aqueous environment", J Chem, 9(4), 2297-2308.

[4] Bensadok, K., Benammar, S., Lapicque, F. and Nezzal, G., (2008) "Electrocoagulation of cutting oil emulsions using aluminum plate electrodes", Journal of Hazardous Materials, Vol. 152, pp: 423-430.

[5] El-Naas, M.H., Alhaija, M.A., Al-Zuhair, S., (2014), "Evaluation of a three-step process for the treatment of petroleum refinery wastewater", J. Environ. Chem. Eng. 2, 56-62.

[6] Erto, A., Moreno-piraján, J. C., \& Moreno-piraja, J. C., (2013), "Magnetite nanoparticles for removal of heavy metals from aqueous solutions: Synthesis and characterization".

[7] Farrokhi, M., Hosseini, S., \& Yang, J. (2014), "Application of $\mathrm{ZnO}$ - Fe 3 O 4 Nanocomposite on the Removal of Azo Dye from Aqueous Solutions: Kinetics and Equilibrium Studies".

[8] Gallo, J., Long, N. J., Aboagye, E.O., (2013), Chem. Soc. Rev. 42, 7816-7833.

[9] Li, Y., Wang, J., Zhao, Y., \& Luan, Z., (2010) "Research on magnetic seeding flocculation for arsenic removal by superconducting magnetic separation", Separation and Purification Technology, 73(2), 264-270.

[10] Mehtap, G., (2009) “A Parametric comparative study of electrocoagulation and coagulation of aqueous suspensions of kaolinite andquartz powders", $\mathrm{PhD}$. thesis, the Graduate school of Natural and applied sciencesof middle east technical university

[11] Nassar, N., (2012) "Iron Oxide Nanoadsorbents for removal of various pollutants from wastewater: An overview", Application of
Adsorbents for Water Pollution Control, (July), 81-118.

[12] Nuñez, P., Hansen, H., K., Aguirre, S., Maureira., C., (2011), "Electrocoagulation of arsenic using iron nanoparticles to treat copper mineral processing wastewater", separation and Purification Technology 79, 285-290

[13]Rahmani, AR., (2008), "Removal of Water Turbidity by the Electrocoagulation Method", J Res Health Sci, Vol. 8, No. 1, pp. 18-24.

[14] Safari, S., Azadi Aghdam, M., \& Kariminia, H. R., (2016) "Electrocoagulation for COD and diesel removal from oily wastewater", International Journal of Environmental Science and Technology, 13(1), 231-242.

[15] Shalaby, A., Nassef, E., Mubark, A., Hussein, M., (2014), "Phosphate removal from wastewater by electrocoagulation using aluminium electrodes", American Journal of Environmental Engineering and Science 2014; 1(5): 90-98

[16] Thamer J.M, Esraa R.A \& Thabit A.A "The 3rd International Conference on Building, Construction and Environmental Engineering (BCEE.3-2017) 23-125/10/2017 University of Technology and University Manofia Egypt.

[17]Tir, M., and Moulai-Mostefa, N., (2008) "Optimization of Oil Removal from Oily Wastewater by Electrocoagulation Using Response Surface Method," Journal of Hazardous Materials, Vol. 158, No. 1, pp: $107-$ 115

[18]Ucar, C., Baskan, M.B., Pala, A., (2013), "Arsenic removal from drinking water by electrocoagulation using iron electrodes", Korean Journal of Chemical Engineering 30(10):18891895

[19] Wang, X.S., Lu, H.J., Liu, F., Ren, J.J., (2011), "Adsorption of lead(II) ions onto magnetite nanoparticles", Adsorpt. Sci. Technol. 26, 407417.

[20]Yu, X., (2017), “Impact of environmental conditions on the sorption behavior of $\mathrm{Pb}$ ( II ) in Na-bentonite suspensions". Journal of Hazardous Materials, 183(1-3), 632-640. 


\title{
عملية تهجين التخثر الكهربائي مع جزيئات المغتتيث النانوية لمعالجة المياه العكرة د. ثامر جاسم محد 1، هليل عطية عبد الكاظم 2،
}

\author{
اقسم الهندسة الكبيباوية، الجامعة التكنولوجية، بغد/د، العراق،yahoo.comer_jasim58@yahom thame \\ 2he.80318@uotechnology.edu.iq فسم الهندسة الكيمياوية، الجامعة التكنولوجية، بغداد، العراق، \\ che.80318@uotechnology.edu.iq الباحث المعثل: هديل عطية عبد الكاظم، البريب الالكترونسي: * \\ نشر في: 31 آب 2019
}

الخلاصة - مع التطور السريع في النانو تكنولوجي، يجري حاليا دراسة استخدام الجزيئات النانو المغناطيسية على نطاق واسع في مجال

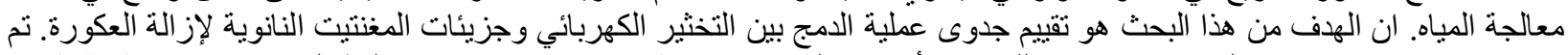

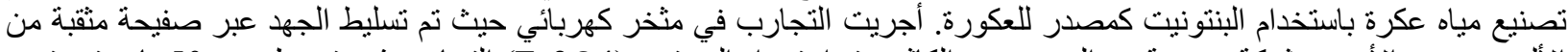

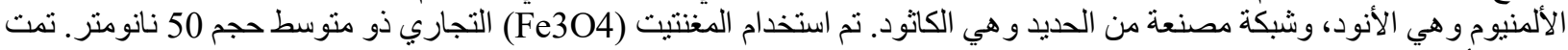

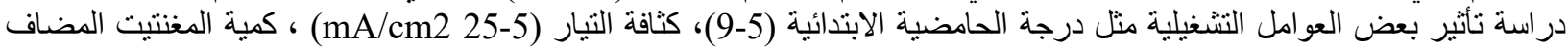

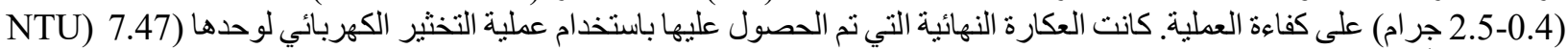

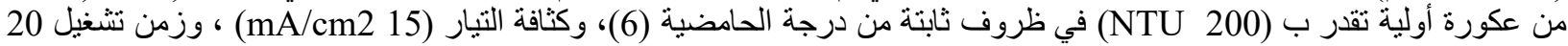

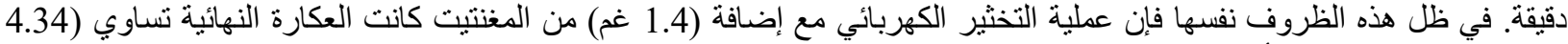
(NTU ) ، وذلك يشير إلى أن الجسيمات النانوية المغنتيت عززت فلير علية التخثير الكهربائي. الكلمات الرئيسية ـ مغنتيت، الجزيئات النانوية، العكورة، معالجة المياه. 